\title{
非単調変位応答スペクトル適合設計用地震動に対する性能指定設計法 PERFORMANCE-BASED DESIGN FOR A BUILDING SUBJECT TO DESIGN EARTHQUAKE WITH NON-MONOTONIC DISPLACEMENT SPECTRUM
}

\author{
过聖晃*1, 永野康行*2, 岡本達雄*3, 上谷宏二*4 \\ Masaaki TSUJI, Yasuyuki NAGANO, Tatsuo OKAMOTO \\ and Koji UETANI
}

\begin{abstract}
The purpose of this paper is to propose a new stiffness design method for shear buildings subject to a design earthquake with non-monotonic displacement spectrum. The objective function that is a combination of the fundamental natural period which represents 'cost' and the level of maximum displacements which represents 'performance' is introduced into the design method to find a set of story stiffness under response constraints. An inverse problem formulation is used to find the stiffness such that the shear building would exhibit maximum interstory drifts proportional to specified ones. Several design examples and time-history analyses are performed to demonstrate the validity and the accuracy of the proposed design method.
\end{abstract}

Keywords : non-monotonic, displacement spectrum, natural period, design earthquakes, performance-based design, stiffness design 非単調, 変位応答スペクトル, 固有周期, 設計用地震動, 性能指定設計, 剛性設計

\section{1. 序}

2000 年 6 月に改正された建築基準法では, 地震荷重に対する新し い安全性唡定の方法として「限界耐力計算」 ${ }^{[1]}$ が導入され，建物の高 さが 60 メートル超える高層建物に加えて, これまで静的な地震力 に対して安全性を㭘定していた低層建物に対しても，建物教地の地 盤状況と地震荷重の動的な性格をより詳細に検討可能な安全性の検 定法を適用することが可能となった。これまでの建築基淮法でも， 振動特性係数 Rt の導入により，低層建物に対する設計用地震荷重の 決定に際して，地盤による地震波の増幅効果が考慮されていた。限 界耐力計算では, より詳細な検討方法により，地盤による地震波の 增幅効果を考慮することが可能となっているといえる。

設計用地震動あるいはそれに対応する設計用応答スペクトルとし ては, 限界耐力計算の場合には次の(1)が，高層建物に対する動的応 答解析においては次の(1) (3)が，一般に用いられている。(1)解放工 学的基盤面での加速度応答スペクトルに，地盤特性により異なる増 幅係数を乗じた地表面での応答スペクトル。(2)建設地周辺の地盤状 況などを考慮して作成した模擬地震波。(3)過去に計測された記録地 震波。

これまでに観測された地震にお抒す地表面での地震波の変位芯答 スペクトルは，全体としてみれば，よく知られているように，固有
周期の増加に対してその值も同様に増加する傾向を有している ${ }^{[2]}$ 。と ころが, 局所的にみれば, 地盤による地震波の増幅効果などにより, 複数の特定の周期にピークを有する「非単調」な様相を呈するのが 通例である。また, 上記(1)および(2)の方法により作成された設計用 地震の地表面での変位応答スペクトルも, 地盤状況によっては, 固 有周期に関して非単調に変化する場合もありうる。

本論文の目的は, 固有周期に関して非単調に変化する变位応答ス ペクトルを有する地震動を設計用地震動とするせ几断型構造物に対 して, 合理的な層剛性の決定法を提案寸ることである。なおここで いう「合理的な層剛性の決定法」とは, 構造物がそのモデル化のレ ベルに応じて設定された設計上の制約を満たし，かつ，ある種の評 価尺度が最小（あるいは最大）となるように, 構造物の煀性を数理 的な手法を用いて決定することを指している。

固有周期の増加に関して単調に増加する変位応答スペクトルを有 する地震動を設計用地震動とするせん断型構造物に対しては, 当該 構造物が指定した層間変位分布をちょうど示すような層剛性分布を 1 次固有振動の卓越性を利用して効率的に見出寸手法が既に確立さ れている ${ }^{[3,4]}$ 。ところが, 固有周期に関して非単調に変化する応答ス ペクトルを有する地震動を設計用地震動とするせん断型構造物の層 剛性を決定する問題に対して, 文献[3]などで提案されている手法を

本論文の一部は, 平成13年日本建築学会近畿支部研究報告集および2001年度日本建築学会大会学術講演梗概集 (関東)に発表している。

${ }^{* 1}$ 京都工芸瀻維大学工芸学部造形工学科 助教授・博士 (工学) $\quad$ Assoc. Prof., Dept. of Architecture and Design, Faculty of Eng. and Design, Kyoto

*2 姝竹中工務店設計部構造担当 修士(工学)

*3 件竹中工務店設計部 部長・博士 (工学)

*4 京都大学大学院工学研究科建築学専攻 教授. 工博 Building Design Dept. Takenaka Corporation, M. Eng.

Senior Manager, Building Design Dept. Takenaka Corporation, Dr. Eng. Prof., Dept. of Architecture and Architectural Systems, Graduate School of Eng.,
Kyoto University, Dr. Eng. 
直接的に適用しようとすると, 次の問題点が生じうる。(A)指定した 層間変位分布をちょうど示寸ような層剛性分布が存在しない。(B)指 定した層間変位分布をちようど示市よう層剛性分布が複数個存在 する。(C)指定した層間変位分布をちょうど示すような層剛性分布を 有するせん断型構造物よりも柔らかく(つまり㑉性に関わるコスト が小さく)，かつ，層間変位も小さいような構造物が存在する。

本論文では，上記の問題点を解決するために，せん断型構造物の 剛性設計問題に対して，1 次固有周期の関数である「コスト」(1 次 固有周期が大きくなれば，乙の值が小さくなるように定義する）と， 層間変位で代表した「性能指標」(層間変位が小さくなればその值が 小さくなるように定義する) の重み付き関数を導入し，その值を最 小上するような㓮性分布を見出寸方法を提案する。この重み付き関 数の導入と, 固有モード逆問題 ${ }^{[3,5]}$ に対する閉形解の有効な利用によ り, 設計者が指定した層間変位分布と相似な層間変位分布を示し, かつ，コストと性能からなる重み付き関数の值を最小とするような せん断型構造物の層剛性分布を容易に見出すことが可能となる。

これまでにも，最適設計理論や逆問題型アプローチに基づいて， 動的外乱を受ける建築骨組構造物に対する数理的構造設計手法が数 多く提案されてきた挒えは 6.7.89]。しかしながら，それらの方法におい て，動的外乱を静的荷重に置き換えるのではなく，直接的に取り扱 う場合には，骨組の動的举動を固有值解析や時刻歴応答解析により 直接的に計算し，その設計感度を用いて骨組断面の最適化を行うこ とを前提としているため，大規模な建築骨組に対しては膨大な計算 負荷が必要となるという問題点を有している。

この問題点に対して著者らは，最初に，所定の動的応答制約を満 た寸せん断型構造物の層特性を逆問題型定式化に基づき見出し, 続 いて，そのせん断型構造物と等価な動特性を有し，かつ，設計用静 的荷重に対する応答制約をも満たすような骨組構造物の各部材断面 を最適設計理論に基づいて見出すという，二段階からなる数理的構 造設計手法を提案している ${ }^{[10,11,12]}$ 。この手法では，骨組構造物の最適 設計においてはその静的举動のみを考慮すればよいため，大きな計 算負荷を必要と寸る動的举動解析を骨組構造物に対して実行するこ とが不要であり，大規模な建築骨組に対しても，これまでに提案さ れている手法に比べて格段に少ない計算時間で所定の制約を満たす 設計を見出すことが可能となる。

本論文で提案する手法によりせん断型構造物の層剛性が決定でき れば，固有周期に関して非単調に変化する応答スペクトルを有する 地震動を受ける構造物に対しても，著者らの提案する方法 ${ }^{[10,11,12]} に よ$ り，層剛性を決定したせん断型構造物の原モデルである骨組構造物 の各部材断面を，合理的かつ効率的に決定できることとなる。

なお，本論文では，建物に生じる最大応答が弾性範囲内にある場 合の設計法を提案しているが，等価線形化手法 ${ }^{[13]}$ を導入して等価剛 性と等価減衰を適切に評価することによって, 最大応答が弾塑性範 囲にまで及ぶ場合についても，本論文で提案する設計法を適用する ことが可能である。

\section{2. 実務における設計用地震動}

構造物の安全性を検定するための設計用地震動の設定方法として は，建築物構造安全性能評洒機関である（財）日本建築センターか ら, 時刻歴応答解析建築物構造安全性評価業務方法書 ${ }^{[14]}$ が出されて
いる。水平方向入力地震動の設定に関する部分を表 1 に転記する。

実務における設計用地震動の一例として，著者ら“2*3 が改正基準法 [1]に基づき建築物構造安全性能評価を受けた 3 つの建築物について の設計採用地震波をサイトごとに分けて表 2 に示す。また，これら の設計用地震動（極めて稀に発生する地震動のレベル）の変位応答 スペクトル (5\%減衰) を図 1 に示す。なお，サイトC 恃地震動入力 位置深さの違いで 2 種類の入力を考えている。これらから，実務に おける設計用地震動は非単調な変位応答スペクトル特性を持つ地震 動であることがわかる。

\section{表 1 時刻歴応答解析時の水平方向入力地震動の設定}

\begin{tabular}{|c|c|}
\hline (1) & 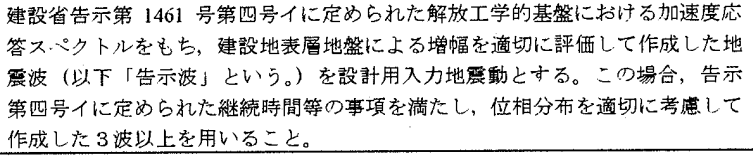 \\
\hline (2) & 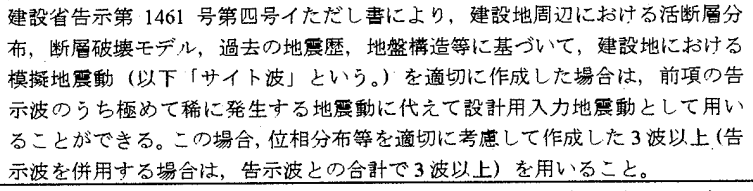 \\
\hline (3) & 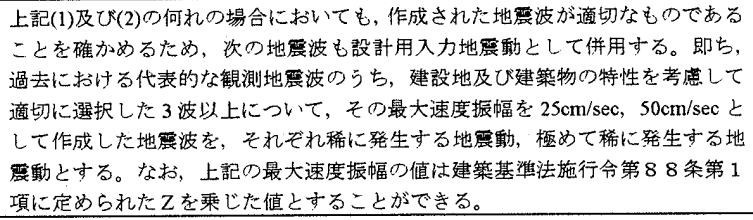 \\
\hline
\end{tabular}

表 2 採用地震波（極めて稀に発生する地震動）

\begin{tabular}{|c|c|c|c|}
\hline \multirow{2}{*}{ サイト } & \multicolumn{3}{|c|}{ 採用地震波 } \\
\hline & 告示波 & サイト波 & 観測地震波 \\
\hline \#1トA & 2波 & 1 波 (上町断層系) & 標準 3 波 ${ }^{*}$ \\
\hline サイトB & 3波 & 1 波（大阪市 L2 $\left.{ }^{[15\}}\right)$ & 標準 3 波* \\
\hline サイトC & 2 波 & 1 波 (生駒断層) & 標準 3 波 ${ }^{*}$ \\
\hline
\end{tabular}

*ここでの標準 3 波とは El Centro 1940 NS，Taft 1952 EW，Hachinohe 1968 NS を指す。
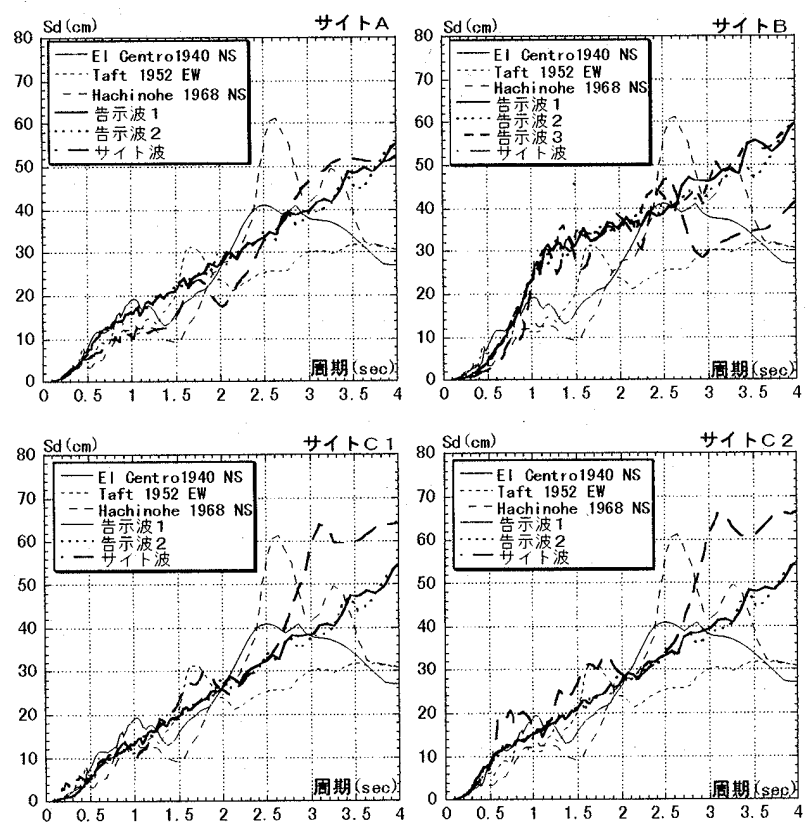

図 1 変位応答スペクトル $(5 \%$ 減衰 $)$ 


\section{3. 非単調变位応答スベクトル適合設計用地震動}

本論文での用語について，以下のように定義しておく。

定義(単調な变位応答スベクトル):異なる固有周期 $T_{1}$ と $T_{2}$ に対して

$$
\dot{T}_{1}<T_{2}
$$

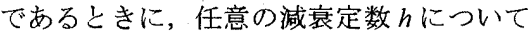

$$
S_{D}\left(T_{1}, h\right) \leqq S_{D}\left(T_{2}, h\right)
$$

が必ず成り立つ変位応答スペクトル $S_{D}(T, h)$ を「単調な変位応答ス ペクトル」と呼ぶ。また, 単調な変位応答スペクトルを有する地震 動を「単調変位スペクトル適合地震動」と呼ぶ。さらに，任意の減 衰定数 $h$ につて

$$
S_{D}\left(T_{1}, h\right)<S_{D}\left(T_{2}, h\right)
$$

が必ず成り立つ変位応答スペクトルを，「狭義に単調な変位応答ス ペクトル」と呼ぶ。

定義(非単調な变位応答スベクトル): 異なる固有周期 $T_{1}$ と $T_{2}$ に対し て $S_{D}\left(T_{1}, h\right)$ と $S_{D}\left(T_{2}, h\right)$ の間に確定した大小関係が存在しない変位 态答スペクトルを「非単調な変位応答スペクトル」と呼ぶ。また， 非単調な変位応答スペクトルに適合する地震動群を「非単調変位ス ペクトル適合地震動」と呼ぶ。

\section{4. 非単調変位応答スベクトル適合設計用地震動に対する設計問題 \\ 4. 1 構造物モデル}

多層建築骨組の層間変位に関わる動特性を表現しうる単純構造物 モデルとして，地表面に剛接された $N$ 層並進せん断型構造物モデル を採用する。この構造物モデルを以下では SB (Shear Building) モデ ルと呼ぶことにする。SB モデルの第 $j$ 層床面集中質量および層剛性 をそれぞれ， $m_{j}$ 扩よび $k_{j}$ で表す。構造减衰特性は, 別途, 応答ス ペクトルの值を評価する際に減衰定数として与えるものとする。

\section{2 応答指定型設計問題とその問題点}

問題 DBD(Displacement-Based Design for a shear building subject to design earthquakes) : SB モデルに対して, 各階質量分布および構造減 衰特性が与えられたとき，変位応答スペクトルに適合する設計用地 震動に対寸る最大層閒変位分布が指定した分布と一致する層判性分 布を決定せよ。

この問題に対して，狭義に単調な変位応答スペクトル適合地震動 が与えられたときの解は, 1 次モードの卓越性を利用した解法により, ほぼ一意に決定できることが Nakamura and Yamaneにより既に示さ れている[3]。

ところが問題 DBD に対して, 非単調変位スペクトル適合地震動が 与えられた場合には，次に示すように 3 つの問題点が生じる場合が ある。

(A)指定した層間変位分布をちようど示すような層剛性分布が存 在しない。

(B)指定した層間変位分布をちょうど示すような層剛性分布が複 数個存在する。

(C)指定した層間変位分布をちょうど示すような層剛性分布を有
するせん断型構造物よりも柔らかく(つまり夙性に関わるコ ストが小さく), かつ，層間変位も小さくなるような層喇性分 布が存在する。

(A)のように等号制約条件に対して解が存在しないような問題に 対しては, 制約条件を不等号制約条件に変え, 目的関数を最小化す るという条件を持ち込めば，最適設計問題に変換することができる。 また，(B)のように解が複数個存在するような問題に対しても，最も 望ましい解を選択するために，目的関数を最小化するという条件を 持ち込めば，最適設計問題に変換することができる。しかしながら， せん断型構造物においては, 設計变数である層剛性と, 対応する(= せん断型椿造物と等価な）骨組構造物のコストとの関倸が明確では ないことと，せん断型構造物を用いている限りは考慮できない実際 上の制約条件が存在することなどから，単純に問題 DBDに対して目 的関数として層剛性によって代表される層剛性のみを導入して最適 設計型の問題に変換しても, 指定した範囲内で最大の固有周期のも のが選ばれるだけで，実際上意義のある問題となるようには思われ ない。

\section{3 非単調変位応答スベクトルに対する剠性設計問題}

実務における動的解析を用いた構造設計の目的は, いくつかの設 計用地震動に対して, 骨組モデルあるいはとれと等価なせん断型モ デルの層間変形角や層塑性率があらかじめ決められた許容值を下回 るように，骨組モデルの各部材サイズを決定寸ることにあり，決め られた許容値とちょうどー致することを要求はしていない。したが って, 性能指定型設計法において, もしも許容值とちょうど一致す るような応答を呈する解が存在せず, それを下回る解しか存在し得 ないのであれば，その中で最も望ましい解を探索する手法を構成す ることは実務上意義のあることである。そこで, 次に示す問題 DBDNM を設定する。

問題 DBDNM(Displacement-Based Design for a shear building subject to design earthquakes with Non-Monotonic displacement spectrum) : S B $モ$ デルに対して, 各階質量分布抒よび構造減衰特性が予め与えられた とき，以下の制約条件

$$
\begin{aligned}
& T_{L} \leqq T^{(\mathrm{l})} \leqq T_{U} \\
& \delta_{j_{\max }}=\alpha \bar{\delta}_{j} \quad(j=1, \ldots N) \\
& \alpha \leqq 1 \\
& \beta=1-T^{(1)} / T_{U}
\end{aligned}
$$

を全て満たし，かつ，目的関数

$$
f=\gamma_{1} \alpha+\gamma_{2} \beta \quad\left(\gamma_{1}+\gamma_{2}=1\right)
$$

を最小とするように層剛性分布 $\left\{k_{j}\right\}$ を求めよ。ただし， $\gamma_{1}$ と $\gamma_{2}$ は 正とする。

ここで, $T_{L}$ および $T_{U}$ は建物の 1 次固有周期 $T^{(\mathrm{l})}$ の上限値および 下限値, $\gamma_{1}$ は層間変位に関寸る重み係数， $\gamma_{2}$ は 1 次固有周期に関寸 る重み係数, $\delta_{j_{\max }}$ は非単調な変位応答スペクトルに適合する設計用 地震動に対する第 $j$ 層の最大層間変位であり, 本論女では応答スペク

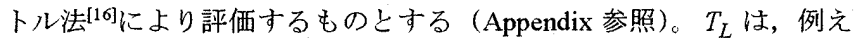
ばコストに対する検討や既往類似物件から設定すればよく， $T_{U}$ は例 えば長期設計のみで決まる場合の固有周期とすればよい。 
問題 DBDNM において， $\alpha$ の值が小さいほど SB モデルの層間変 位は小さくなるので， $\alpha$ は構造物の「性能」を代表するパラメタで あるといえる。そこで， $\alpha$ を本研究では「性能指標」と呼ぶことと する。一方， $\beta$ の值が小さいほじ $\mathrm{SB}$ モデルの 1 次固有周期は長く なるので，(5)式の条件下では $\beta$ の值が小さいほど層剛性が小さくな ることとなる。つまり $\beta$ は構造物の「コスト」を代表するパラメ夕 であるといえる。したがって， $\gamma_{1}$ は性能に関する重み係数， $\gamma_{2}$ はコ ストに関寸る重み係数となり，設計者は，性能とコストのどちらを 重視寸るかにより， $\gamma_{1}$ と $\gamma_{2}$ の值老決めることになる。なお，目的関 数 $f$ の定義式(8)は, 建物の総合評価之性能代表パラメタ $\alpha$ およびコ スト代表パラメタ $\beta$ がそれぞれ線形の関係にあるという条件のもと で設定した関数である。目的関数 $f$ が $\alpha$ および $\beta$ の関数でさえあれ ば，以下の定式化に変更は必要ない。

問題 DBDNM では, 設計用地震動に対する最大層間変位の上限を 設定寸るのではなく，(5)式で表現されているように, 設計用地震動 に対寸る最大層間変位の分布形状が設計者の指定したものと一致す るような制約を設定した。これは, 層間変位の上限のみを制約条件 とした場合，解であるせん断型構造物が呈する層間変位分布は，か ならずしも設定した上限值に一致するとは限らず, その結果として， 極めて稀に発生するレベルの地震動に対しては，特定の層に塑性変 形が集中する可能性があるためである。また，中間層免震建物など の，特定層の変形を他層に比べ極端に大きくしてその層をエネルギ 一吸収機構として利用寸る建物の層剛性の決定問題に対しても，(5) 式の制約条件は直接的に対応が可能である。

\section{4 問題 DBDNM の解構造}

高層建物の水平方向地震動に対寸る応答においては，上く知られ ているように，1次モードがその主たる役割を果たしている。そこ で，問題 DBDNM の解がじのような性質を持つのかを明らかにする ために，地震時最大応答を 1 次モードのみで評価することとする以 下の問題 FMBDNM を考える。

問題 FMBDNM(Fundamental Modal Based Design for a shear building subject to design earthquakes with Non-Monotonic displacement spectrum)：SBモデルに対して, 各階質量分布および構造減衰特性が 予め与えられたとき，制約条件(4)，(6)，(7)および

$$
\delta_{j}^{(1)}=\alpha \bar{\delta}_{j} \quad(j=1, \ldots . N)
$$

を全て満たし, かつ, 目的関数(8)を最小上するように層剛性分布 $\left\{k_{j}\right\}$ を求めよ。

$\delta_{j}^{(1)}$ は 1 次モードのみで評価した, 設計用地震動に対寸る第 $j$ 層の 層間変位であり, 次式で表される。

$$
\delta_{j}^{(1)}=v^{(1)} S_{D}^{(1)}\left(u_{j}^{(1)}-u_{j-1}^{(1)}\right)
$$

ここで, $v^{(1)}$ は 1 次の刺激係数, $S_{D}^{(1)}$ は 1 次の固有周期上減衰定数 に対応寸る 1 次の変位応答スペクトル， $u_{j}^{(1)}$ は 1 次水平変形固有ベ クトル成分を表す。

問題 FMBDNM に対寸る解は, 以下のようにして導くことができ る。(10)式に対して正規化条件

$$
v^{(1)} S_{D}^{(1)}=1
$$

を導入し，(11)式を考慮すると，

$$
\delta_{j}^{(1)}=u_{j}^{(1)}-u_{j-1}^{(1)}=\alpha \delta_{j}
$$

すなわち(11)式を満足する SB モデルの1 次固有ベクトル成分として,

$$
u_{j}^{(1)}=\sum_{i=1}^{j} \delta_{j}{ }^{(1)}=\alpha \sum_{i=1}^{j} \bar{\delta}_{i}
$$

を得るここような固有べクトル成分をもつS B モデルの第 $j$ 層の層 剛性 $k_{j}$ は, 固有モード逆問題に対する閉形解 ${ }^{[3]}$ を用いて, $\beta$ を末知 数として以下のように書ける。

$$
\begin{aligned}
k_{j} & =\left(\frac{2 \pi}{T^{(1)}}\right)^{2} \frac{\sum_{i=j}^{N} m_{i} u_{i}^{(1)}}{u_{j}^{(1)}-u_{j-1}{ }^{(1)}}=\left(\frac{2 \pi}{T^{(1)}}\right)^{2} \frac{\sum_{i=j}^{N} m_{i} \alpha \sum_{\ell=1}^{i} \bar{\delta}_{\ell}}{\alpha \bar{\delta}_{j}} \\
& =\left(\frac{2 \pi}{T_{U}-\beta T_{U}}\right)^{2} \frac{\sum_{i=j}^{N} m_{i} \sum_{\ell=1}^{i} \bar{\delta}_{\ell}}{\bar{\delta}_{j}}
\end{aligned}
$$

刺激係数 $\nu^{(1)}$ は, その定義式 (Appendix 参照) と，(13)式を考慮する と

$$
\begin{aligned}
v^{(1)} & =\frac{\sum_{i=1}^{N} m_{i} u_{i}^{(1)}}{\sum_{i=1}^{N} m_{i} u_{i}^{(1)^{2}}}=\frac{\sum_{i=1}^{N} m_{i} \alpha \sum_{\ell=1}^{i} \bar{\delta}_{\ell}}{\sum_{i=1}^{N} m_{i}\left(\alpha \sum_{\ell=1}^{i} \bar{\delta}_{\ell}\right)^{2}}=\frac{1}{\alpha} \frac{\sum_{i=1}^{N} m_{i} \sum_{\ell=1}^{i} \bar{\delta}_{\ell}}{\sum_{i=1}^{N} m_{i}\left(\sum_{\ell=1}^{i} \bar{\delta}_{\ell}\right)^{2}} \\
& =\frac{1}{\alpha} v^{-(1)}
\end{aligned}
$$

と書けるので, 正規化条件(11)より， $\alpha$ と応答スペクトル $S_{D}^{(1)}$ の間に 以下の関係式が書ける。

$$
\alpha=\bar{v}^{-(1)} S_{D}{ }^{(1)}
$$

ここで, $S_{D}^{(1)}$ は $T^{(1)}$ の関数であるから， $\beta$ の関数であるともいえる。 そこでこれを $\widetilde{S}_{D}(\beta)$ と表すことにすると，

$$
\alpha=\bar{v}^{(1)} \tilde{S}_{D}(\beta)
$$

すなわち， $\beta$ を与えると, (17)式より, 問題 FMBDNM の制約条件 のうち等号制約条件(7)式および(9)式を満たす $\alpha$ の值が計算できる ことになる。(17)式に加えて，不等号制約条件(4)式执よび(6)式を満 足するような $\alpha$ と $\beta$ の関倸を, 設計に用いる応答スペクトルの図と 対照させて図示すると図 2 のようなる。ただし，この図は，ある 非単調設計用応答スペクトルに対して, $N=10, T_{L}=0.8 \mathrm{sec}, T_{U}=1.8 \mathrm{sec}$, $\bar{\delta}_{j}=2.0 \mathrm{~cm}$ の場合を例として描いたものである。
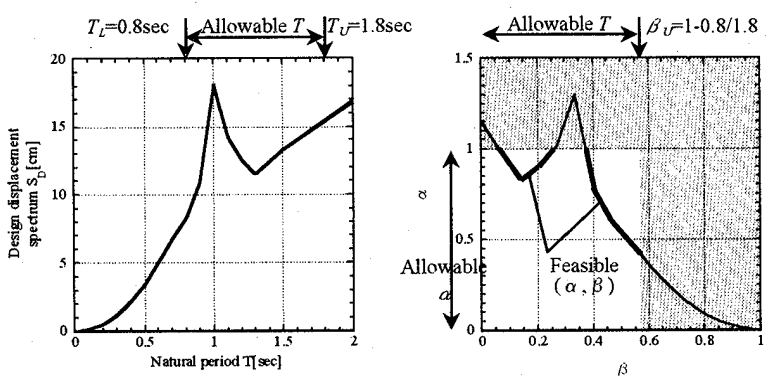

図 2 変位応答スペクトルと $\alpha-\beta$ の対応関係

目的関数(8)式を最小化するような $\alpha$ と $\beta$ の解は等高線 $(8)$ と (4)(6)(7)(9)式を満たす $\alpha-\beta$ 曲線の接点あるいは端点となる。図 3 に, 異なる 3 通りの $\alpha$ と $\beta$ の組み合わせに対して, 目的関数 $f$ が最 小となる点を白丸 $(O)$ で示す。

( i ) $\gamma_{1}=0, \gamma_{2}=1$ 即ち「コスト」重視の場合

(ii) $\gamma_{1}=1, \gamma_{2}=0$ 即ち「性能」重視の場合 
(iii) $\gamma_{1}, \gamma_{2}$ の値が設計者が定めた，ある值 (例えば $\gamma_{1}=0.5, \gamma_{2}=0.5$ ) の場合

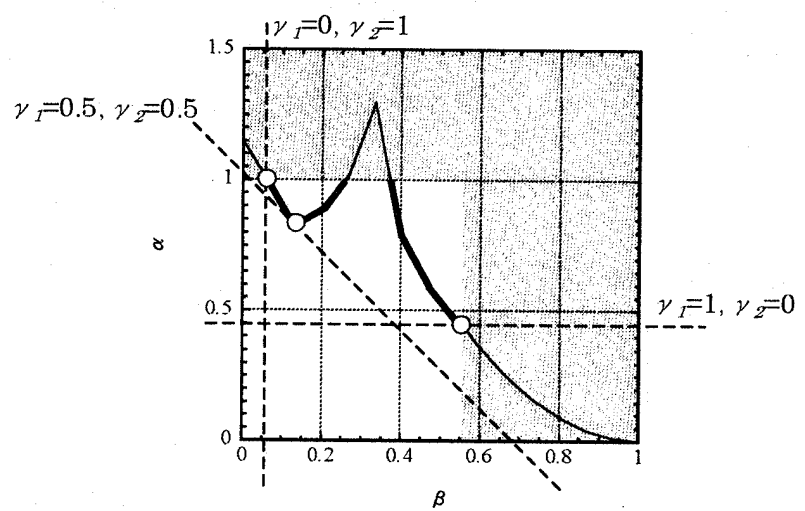

図 $3 \alpha-\beta$ 曲線之目的関数 $f$ 対応関係図

なお，図 3 の白抜きで示した実行可能領域に，設計用地震動の忘 答スペクトルから計算される $\alpha-\beta$ 関係曲線がない場合には, 目標 とする層間変形角レベルの変更や, 制振装置の導入による減衰性能 の向上など, 構造計画からの再検討が必要であることを意味してい る。また， $\alpha-\beta$ 関係曲線と目的関数の等高線が複数箇所で接して， 解が複数個存在するようになった場合には，さらに別の評価尺度を 導入すればよい。

\section{5 問題 DBDNM の解法}

前述したように，高層建物の水平方向地震動に対する忍答におい ては，1 次モードがその大部分を占めている。したがって, 問題 FMNDNM の解は, 問題 DBDNM の第一近似解になっていると考え てよい。そこで, 問題 DBDNMに対しても, 問題 FMBDNMに対す る解と, 地震応答に㧍ける 1 次固有振動の卓越性を有効に利用して, 効率的な解法を構成することが可能である。以下にその手順を示す。 [Step0]地震時最大忘答の全てを 1 次固有振動成分 $\delta_{J}^{(1)}$ が占めている と仮定して $\bar{\delta}_{j}^{(\mathrm{l})}=\bar{\delta}_{j}$ とする。

[Step1] $\bar{\delta}_{j}=\bar{\delta}_{j}^{(1)}$ として問題 FMBDNM を解き, SB モデルの層剛性分 布を求める。

[Step2]固有值解析を実行し, 応答スペクトル法により SB モデルの最 大層間変位分布を計算する。

[Step3](5)式が所定の精度で満足されているかどうかを検定寸る。満 足されていれば SB モデルにおいて(5)式が満足されているとみなし 終了する。(5)式が所定の精度で満足されていなければ, 次式

$$
\delta_{j_{\text {updated }}}^{(1)}=\left(\bar{\delta}_{j}^{(1)} / \delta_{j \max }\right) \bar{\delta}_{j}
$$

に従って 1 次固有振動成分を改修し $\bar{\delta}_{j}{ }^{(1)}=\delta_{j_{\text {updated }}}^{(1)}$ として Step1 に もどる。

\section{5. 例題}

非単調な設計用変位态答スペクトルの 1 例として, 観測地震波 （Taft 1952EW，最大速度振幅 $25 \mathrm{~cm} / \mathrm{sec}$ ）の応答スペクトルを設計用 地震動として採用した場合の例を示す。以下の例題において，减衰
は剛性比例型とし, 高次の减衰定数 $h$ に対寸る応答スペクトルの低 减は文献[17]にならい, $h=0.02$ の值を $1.2 /(1+10 h)$ 倍で変位応答スペク トルを低減することとする。

例題 1: SB モデルの諸元を $N=10$ 層, $m_{j}=1000$ (ton) for all $j, 1$ 次の 減衰定数 $h=0.02, \bar{\delta}_{j}=2.0 \mathrm{~cm}$ とし, 1 次固有周期の範囲を $T_{L}=0.8 \mathrm{sec}$ $T_{U}=1.8 \mathrm{sec}$ とする。また, 応答評価法として SRSS 法を採用(Appendix 参照) する。

まず，問題 FMBDNM に対する解を示す。 $S_{D}-T$ 関倸を表した図 上に, $S_{D}=0$ と $T=T_{U}$ を起点として, 縦軸に $\alpha / \bar{v}^{-(1)}$ を, 横軸に $\beta T_{U}$ をとることで, 制約条件を満足する $\alpha-\beta$ 関係を容易に描くことが できる。それを図4に示す。

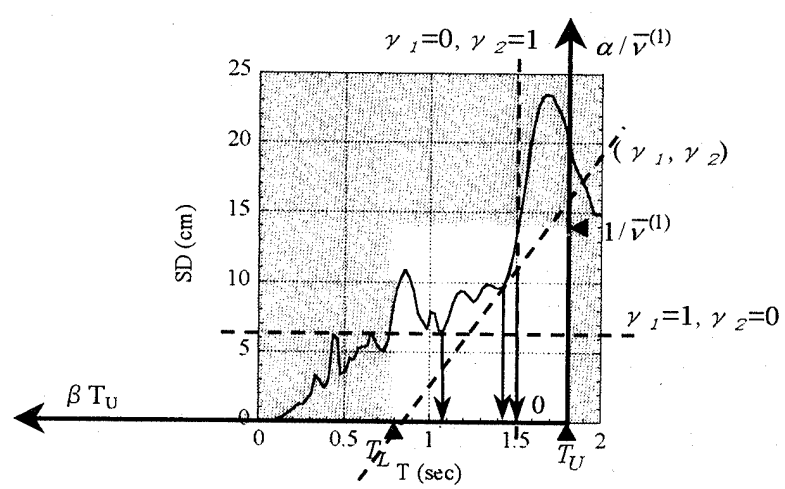

図 4 変位応答スペクトル（2\%減衰）と $\alpha-\beta$ の関係 1

図 4 から，目的関数 $f$ を最小とする固有周期は， $\gamma_{1}$ の変化に対し て連続に変化するのではなく, 不連続に変化して決定される様子が 観察される。

次に，4５節に示した解法を用い問題 DBDNMに対して求めた 層剛性を以下に示寸。以下には; $\left(\gamma_{1}, \gamma_{2}\right)=(0.0,1.0),(0.5,0.5)$, $(1.0,0.0)$ の 3 ケース（以下それぞれケース $1 ，$ ケース 2 , ケース 3 と 呼ぶ）について求められた層剛性分布及び $\alpha$ の值を表 3 に示す。

応答評価を, SRSS 法による值と ABS 法による值の平均により行 った場合について, ケース 1〜ケース 3 について問題 DBDNM に対 する, 求められた層剛性分布及び $\alpha$ の值を表 3 にあわせて示寸。

表 3 層剖性分布（10 層モデル例）

\begin{tabular}{c|c|c|c|c|c|c}
\hline \multirow{2}{*}{ 層 } & \multicolumn{9}{|c|}{ 層岡性 $\left(\times 10^{7} \mathrm{~N} / \mathrm{m}\right)$} \\
\cline { 2 - 7 } & \multicolumn{2}{|c}{ ケース } & \multicolumn{2}{|c}{ ケース 2} & \multicolumn{2}{c}{ ケース 3 } \\
\cline { 2 - 7 } & SRSS & 平均* & SRSS & 平均* & SRSS & 平均* \\
\hline 10 & 22.9 & 32.3 & 46.8 & 55.2 & 48.5 & 56.7 \\
\hline 9 & 37.5 & 47.2 & 76.6 & 83.9 & 79.3 & 86.3 \\
\hline 8 & 48.8 & 55.7 & 97.9 & 103.5 & 101.5 & 106.7 \\
\hline 7 & 58.4 & 65.3 & 113.8 & 119.4 & 118.5 & 124.4 \\
\hline 6 & 66.8 & 71.8 & 127.2 & 127.7 & 133.3 & 134.0 \\
\hline 5 & 74.2 & 74.7 & 140.3 & 132.8 & 147.6 & 140.1 \\
\hline 4 & 81.0 & 80.7 & 153.5 & 146.9 & 161.5 & 155.0 \\
\hline 3 & 86.9 & 86.4 & 166.0 & 160.3 & 174.5 & 168.4 \\
\hline 2 & 91.7 & 95.7 & 176.4 & 175.9 & 185.1 & 184.3 \\
\hline 1 & 94.6 & 104.4 & 182.5 & 189.2 & 191.2 & 197.8 \\
\hline$\alpha$ & 1.00 & 1.00 & 0.52 & 0.59 & 0.50 & 0.58 \\
\hline
\end{tabular}

*表 3 中「平均」とは，応签評価を，SRSS 法による值と ABS 法による值の平均により評価 した場合の層㣚性を示す。 
表 3からわかるように, SRSS 法により応答を評価する場合よりも， SRSS 法による值と ABS 法による值の平均により応答を評価をした 場合の方が，より大きな層剛性が得られている。また，ケース 1 か らケース 2, ケース 3 となるにしたがって, 得られる層剛性は大きく なり，その結果 $\alpha$ の值も小さなものとなることもわかる。

例題 $2: \mathrm{SB}$ モデルの諸元を $N=20$ 層, $m_{j}=1000$ (ton) for all $j, 1$ 次の 减衰定数 $h=0.02, \bar{\delta}_{j}=2.0 \mathrm{~cm}$ 之ᄂ, 1 次固有周期の範囲を $T_{L}=1.6 \mathrm{sec}$, $T_{U}=3.6 \mathrm{sec}$ とする。本例題では, 忘答評価法として SRSS 法を採用 した場合と，SRSS 法による値とABS 法による值の平均により忘答 評価した場合の層剛性分布の両者を示す。

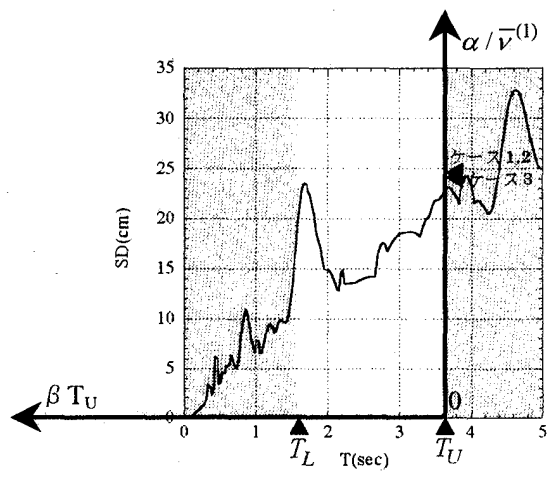

図 5 変位応答スペクトル $(2 \%$ 减衰 $) と \alpha-\beta$ の関倸 2

$\gamma_{1}$ と $\gamma_{2}$ の組み合わせは, 例題 1 と同様の 3 ケースを設定し, 例題 1 と同様にケース 1 , ケース 2, ケース 3 上呼ぶことにする。ケース 1〜ケース 3 について問題DBDNMに対して求められた層剛性分布及 び $\alpha$ の值を表 4 に示す。設計用変位岕答スペクトル上に， $S_{D}=0$ 上 $T=T_{U^{\prime}}$ を起点として， $\alpha / \bar{v}^{-(1)}-\beta T_{U}$ 軸を描いたものを図 5 に示寸。 図中に示したしは，応答評価法として SRSS 法を評価した場合の各

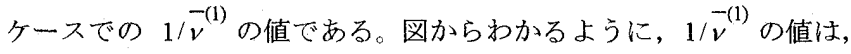
$\gamma_{1}$ と $\gamma_{2}$ の組み合わせによらず，ほぼ同じ値となっている。

表 4 層剛性分布（20 層モデル例）

\begin{tabular}{|c|c|c|c|c|c|c|}
\hline \multirow{3}{*}{ 層 } & \multicolumn{6}{|c|}{ 層剛性 $\left(\times 10^{7} \mathrm{~N} / \mathrm{m}\right)$} \\
\hline & \multicolumn{2}{|c|}{ ケ-ス1 } & \multicolumn{2}{|c|}{$3-\pi 2$} & \multicolumn{2}{|c|}{ ケース 3} \\
\hline & SRSS & 平均* & SRSS & 平均* & SRSS & 平均* \\
\hline 20 & 12.6 & 19.7 & 15.4 & 31.8 & 32.9 & 41.3 \\
\hline 19 & 19.8 & 28.1 & 22.7 & 46.6 & 55.3 & 63.9 \\
\hline 18 & 24.5 & 33.3 & 28.4 & 54.0 & 72.4 & 79.0 \\
\hline 17 & 27.8 & 38.6 & 33.7 & 59.3 & 85.8 & 90.4 \\
\hline 16 & 30.7 & 43.0 & 37.9 & 65.3 & 96.3 & 101.1 \\
\hline 15 & 33.6 & 45.8 & 41.2 & 70.4 & 104.1 & 108.5 \\
\hline 14 & 36.8 & 47.7 & 44.5 & 73.3 & 109.8 & 113.7 \\
\hline 13 & 40.1 & 51.0 & 48.0 & 78.5 & 114.0 & 120.4 \\
\hline 12 & 43.3 & 53.4 & 51.3 & 82.4 & 117.5 & 123.5 \\
\hline 11 & 46.1 & 53.9 & 54.1 & 79.5 & 121.1 & 123.2 \\
\hline 10 & 48.4 & 55.0 & 56.5 & 84.4 & 125.4 & 125.0 \\
\hline 9 & 50.4 & 54.9 & 58.9 & 85.5 & 130.6 & 125.3 \\
\hline 8 & 52.0 & 57.2 & 61.5 & 89.2 & 136.8 & 131.1 \\
\hline 7 & 53.6 & 60.8 & 64.2 & 93.9 & 143.6 . & 139.4 \\
\hline 6 & 55.3 & 63.3 & 66.6 & 95.6 & 150.8 & 145.1 \\
\hline 5 & 57.3 & 65.6 & 68.7 & 97.7 & 158.0 & 148.3 \\
\hline 4 & 59.4 & 67.5 & 70.8 & 101.0 & 165.0 & 159.8 \\
\hline 3 & 61.4 & 70.7 & 73.1 & 108.3 & 171.2 & 169.1 \\
\hline 2 & 63.2 & 75.8 & 75.2 & 117.1 & 176.0 & 179.6 \\
\hline 1 & 64.3 & 80.8 & 76.6 & 124.7 & 178.7 & 187.9 \\
\hline$\alpha$ & 1.00 & 1.00 & 0.75 & 0.79 & 0.54 & 0.68 \\
\hline
\end{tabular}

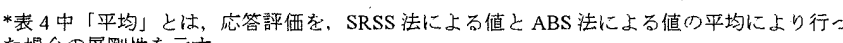
た場台门層闹性を示す。

\section{6. 地震応答解析結果との比較}

例題 1 で得られた層剖性分布を持つ $\mathrm{SB}$ モデルに対して, 設計に用 いた応答スペクトルの原波（Taft 1952EW，最大速度振幅 $25 \mathrm{~cm} / \mathrm{sec}$ ) を作用させて時刻歴応答解析を行った。解析アルゴリズムには Newmark- $\beta$ 法を用いた。それぞれの設計に対寸る最大層間変形角分 布を図6に示す。
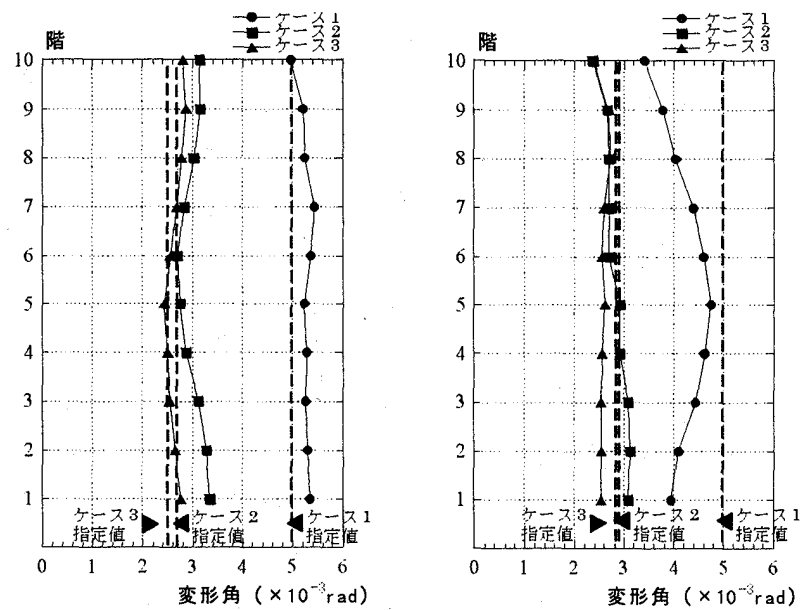

(a)SRSS 応答評価の場合 (b)(SRSS $+A B S) / 2$ 応答評価の場合 図 6 層間変形角応答 (10 層モデル例)

例題 2 で得られた層剛性分布を持つSB モデルに対して, 同じ地震 波を作用させて時刻歴応答解析を行った。それぞれの設計に対寸る 最大層閒変形角分布を図 7 に示す。
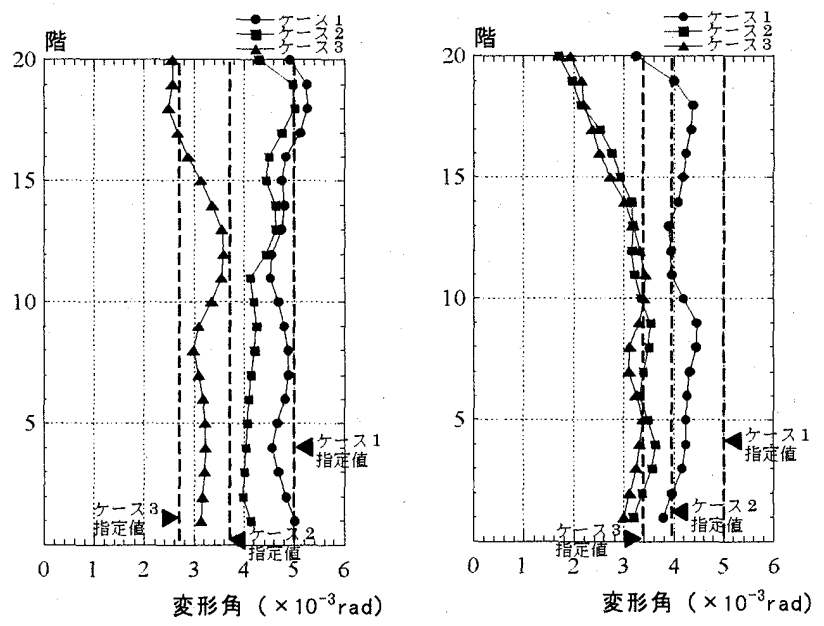

(a)SRSS 応答評価の場合 (b)(SRSS+ABS)/2 応答評価の場合 図 7 層間変形角応答（20 層モデル例）

図 6 および図 7 から，10 層モデル，20 層モデルのいずれにおいて も，層剛性設計時の応答評価を SRSS 法により行った場合は，20層 モデルのケース 1 を除く全てのケースにおいて，ほぼ全ての層で時 刻歴解析による最大応答值が目標値を上回る結果となり，一方，応 答評価を SRSS 法による值とABS 法による值の平均により行った場 合は，時刻歴解析による最大忘答值が目標值をほぼ下回る結果とな ることが観察される。 


\section{7. 複数の地震動を設計用地震動とする場合への適用}

本論文では，非単調な変位応答スペクトルを有する単独の設計用 地震動に対する剛性設計問題を設定し，その解法を示した。設計用 地震動として複数の地震動を採用する場合には，それらの変位応答 スペクトルを包絡するスペクトルを設計用応答スペクトルとすれば, 本論文で提案した手法をそのまま適用することが可能である。

\section{8. 結論}

本論文で得られた成果は以下のとおりである。

1. 非単調変位応答スペクトルに適合した設計用地震動に対するせん 断型構造物の哃性設計問題に， 1 次固有周期の関数である「コス 卜」と，層間変位で代表した「性能指標」の重みつき和を目的関 数として導入し, その值を最小とするような剛性分布を, 固有乇 一ド逆問題に対する閉形解を有効に用いて見出す方法を提案した。 2.表層地盤の増幅などを考慮した設計用入力地震動に対して本論文 において提案した手法を適用すれば，今まで経験的に行われてき た構造物の構造設計に対して,「コスト」と「性能」のバランスを 定量化した性能指定型の構造設計を行うことが可能となる。

なお本論文では，論理の基本展開を示すために，せん断構造物モ デルを層剛性設計の対象とする構造物モデルとして用いたが，本論 文で提案する層剛性設計手法は，粘性ダンパーなどの制振（震）装 置を有するせん断型構造物モデルや，立体せん断型構造物モデルな ど，設計の対象となる建築骨組に応じたより高度な縮小構造物モデ ルに対しても容易に拡張することが可能である。

\section{謝辞}

竹脇 出 博士 (京都大学助教授), 大崎 純 博士 (京都大学助教授) から貴重な助言を頂戴した。ここに記して謝意を表す。

\section{参考文献}

[1] 平成 12 年 6 月施行 改正建築基準法 (2 年目施行) の解説, 建設省住宅局 建築指導課, 新日本法規, 平成 12 年

[2] 柴田明徳：耐震耐震棈造解析, 森北出版 (1981)

[3] T. Nakamura and T. Yamane : Optimum Design and Earthquake-Response Constrained Design of Elastic Shear Buildings, Earthquake Engng. Struct. Dyn., Vol. 14, pp.798-815 (1986)

[4] T. Nakamura and I. Takewaki : Earthquake-Response Constrained Design of PileSupported Elastic Shear Buildings for Site-Dependent Response Spectra. Proc. 9WCEE, Tokyo-Kyoto, Japan, V, pp. 1043-1048 (1988).

[5] Gladwell, G. M. L. : The Inverse Mode Problem for Lumped-Mass Systems, Q. J. Mech. Appl. Math., Vol.39, pp. 297-307 (1986).

[6] Cheng, F. Y. and Botkin. M., 'Nonlinear Optimal Design of Dynamic Damped Frames, : Proc. ASCE, ST3, Vol.102, pp.609-627 (1976)

[7] Austin, Mark A. and Pister, Karl S. : Design of Seismic-Resistant Friction-Braced Frames, J. Struct. Engng., ASCE, Vol.111, No. 12, pp.2751-2769 (1985).

[8] 内村均、佐藤和英、和田章、黒正清治 : 層間変位に注目した鉄骨骨組の部 材断面変更法小、構造工学における数値解析シンポジウム論文集、第 17 巻、 pp.421-426 (1993).

[9] Chan, Chun-Man, Grierson, Donald E., and Sherbourne, Archibald N. : Automatic Optimal Design of Tall Steel Building Frameworks, J. Struct. Engng., ASCE, Vol.121. No.5, pp.838-847 (1995)

[10] 竹脇出，杉山哲彦，辻聖晃，上谷宏二：縮䄪モデル一骨組逆置換法に基 づく骨組設計法, 日本建築学会構造系論文集, No. 512, pp.119-126(1998) [11] 辻聖晃, 竹脇出, 上谷宏二：せん断型モデルの応答制約設計解老用いた 建築骨租の最適設計法, 平成 11 年度日本建築学会近畿支部研究報告集, pp.117-120 (1999).

[12] M. Tsuji, Y. Nagano, M. Ohsaki, and K. Uetani : Optimum Design Method for High-Rise Building Frame with Viscous Dampers, Proc. 12th WCEE. CD-ROM, New Zealand (2000)

[13] Caughey, T. K., 'Equivalent Linearization Techniques,' J, acous. soc. Am., 35. 1706-1711 (1963)

[14]（財）日本建築センター，時刻歴応答解析建築物性能評価業務方法書の 変更に関するお知らせ (その2)(2001.6.27) http://www.bcj.or.jp/src/hyotei41.pdf [15] 大阪市土木・建築物震災対策技術検討会報告書, 平成 9 年 3 月

[16] Wiegel (Editor), “Earthquake Engineering”, Prentice Hall.pp.403-424

[17] 建築耐震設計における保有耐力と変形性能(1990), 日本建築学会

\section{Appendix SRSS 応答評価法及び ABS 応答評価法について}

弹性せん断構造物に対する非減衰固有振動の支配式は次式のよう に畫ける。

$$
\left(-\omega^{(r)^{2}} \mathbf{M}+\mathbf{K}\right) \mathbf{u}^{(r)}=\mathbf{0}
$$

ここで， $\mathrm{M}$ 法質量行列を， $\mathrm{K}$ は㓮性行列を表し， $\omega^{(r)}$ 女 $\mathbf{u}^{(r)}$ は乙 れぞれ第 $r$ 次固有円振動数と第 $r$ 次固有ベクトルを表す。 $N$ 層せん断 型構造物では， $\mathbf{M}$ の第 $i$ 行 $j$ 列成分 $m_{i j}$ と $\mathbf{K}$ の第 $i$ 行 $j$ 列成分 $k_{i j}$ は それぞれ以下のようになる。

$$
m_{i j}=\left\{\begin{array}{ll}
m_{i} & (i=j) \\
0 & (i \neq j)
\end{array}, \quad k_{i j}= \begin{cases}k_{i}+k_{i+1} & (i=j) \\
-k_{i+1} & (i=j-1) \\
-k_{i} & (i=j+1) \\
0 & \text { (in other cases) }\end{cases}\right.
$$

水平地動に対する第 $r$ 次刺激係数は, 次式のように書ける。

$$
v^{(r)}=\frac{\mathbf{u}^{(r)^{T}} \mathbf{M 1}}{\mathbf{u}^{(r)^{T}} \mathbf{M} \mathbf{u}^{(1)}}=\frac{\sum_{j=1}^{N} m_{j} u_{j}^{(r)}}{\sum_{j=1}^{N} m_{j} u_{j}^{(r)^{2}}}
$$

ここで，１は各成分を１とするベクトルである。上添え字 $T$ は転置 を表す。水平地動 $y_{g}$ を受けるときの第 $j$ 層と第 $j-1$ 層の層間変位の 時刻歷 $\delta_{j}(t)$ は, 固有円振動数が $\omega^{(r)}$ で減衰定数が $h^{(r)}$ であるような 一自由度系の地動 $y_{g}$ に対する変位答の時刻歴 $q^{(r)}(t)$ を用いて, 以 下のモード合成式により表すことができる。

$$
\delta_{j}(t)=\sum_{r=1}^{N} v^{(r)}\left(u_{j}{ }^{(r)}-u_{j-1}{ }^{(r)}\right) q^{(r)}(t)
$$

ここで, $u_{j}^{(r)}$ は $\mathbf{u}^{(r)}$ の第 $j$ 行成分である。

SRSS 応答評価法は, $\delta_{j}(t)$ の最大值 $\delta_{j \max }$ を, $\delta_{j}(t)$ における各次 のモ一ド成分 $v^{(r)}\left(u_{j}{ }^{(r)}-u_{j-1}{ }^{(r)}\right) q^{(r)}(t)$ の最大值の三乗和平方により 評価する方法であり， $\delta_{j \max }$ は次式で表される。

$$
\delta_{j \max }=\sqrt{\sum_{r=1}^{N}\left\{v^{(r)}\left(u_{j}{ }^{(r)}-u_{j-1}^{(r)}\right) S_{D}{ }^{(r)}\right\}^{2}}
$$

ここで, $S_{D}{ }^{(r)}$ は $q^{(r)}(t)$ の最大值であり, 固有円振動数が $\omega^{(r)}$ で減 衰定数が $h^{(r)}$ のときの変位応答スペクトルの值を表す

一方, 。ABS 応答評価法は, $\delta_{j \max }$ 女, $v^{(r)}\left(u_{j}{ }^{(r)}-u_{j-i}{ }^{(r)}\right) q^{(r)}(t)$ の 最大值の絶対值和により評価する方法であり， $\delta_{j \max }$ は次式で表さ れる。

$$
\delta_{j \max }=\sum_{r=1}^{N}\left|v^{(r)}\left(u_{j}{ }^{(r)}-u_{j-1}{ }^{(r)}\right) S_{D}{ }^{(r)}\right|
$$

ABS 応答評価法は, その定義から明らかなように, 時刻歴応答解析 により得られる最大応答值の上界を与える。

（2001年11月 8 日原稿受理，2002年 1 月 16 日採用決定） 